\title{
Anticitrullinated Protein Antibodies and Rheumatoid Factor Fluctuate in Early Inflammatory Arthritis and Do Not Predict Clinical Outcomes
}

Lillian Barra, Vivian Bykerk, Janet E. Pope, Boulos P. Haraoui, Carol A. Hitchon, J. Carter Thorne, Edward C. Keystone, Gilles Boire, And The Catch Investigators

\begin{abstract}
Objective. In inflammatory arthritis, rheumatoid factor (RF) and anticitrullinated protein antibodies (ACPA) are believed to be associated with more severe clinical outcomes. Our objective was to determine whether ACPA and RF remain stable in early inflammatory arthritis and whether their trajectories over time or baseline levels predicted clinical outcomes.

Methods. The study population consisted of patients enrolled in the Canadian Early Arthritis Cohort Study with baseline and at least 12-month followup values of RF and ACPA. Primary outcomes were Disease Activity Score (DAS) remission and the presence of erosions at 12 and 24 months. Other objectives included swollen joint count, Health Assessment Questionnaire score, and DAS.

Results. At baseline, 225/342 (66\%) patients were ACPA-positive and 334/520 (64\%) were RF-positive. At 24 months, 15/181 (8\%) ACPA-positive patients became negative. A larger number of patients changed from ACPA-negative to positive: 13/123 (11\%). For RF, fluctuations were more common: $67 / 240$ (28\%) reverted from positive to negative and 21/136 (18\%) converted from negative to positive. RF and ACPA fluctuations did not predict disease outcomes. Patients who remained ACPA-positive throughout followup were more likely to have erosive disease (OR 3.86, $95 \%$ CI $1.68,8.92)$.

Conclusion. RF and ACPA have the potential to revert and convert during the early course of disease. Fluctuations in RF and ACPA were not associated with clinical outcomes. (First Release Feb 1 2013; J Rheumatol 2013;40:1259-67; doi:10.3899/jrheum.120736)
\end{abstract}

Key Indexing Terms:

ANTICITRULLINATED PROTEIN ANTIBODIES RHEUMATOID ARTHRITIS

EROSIONS

\section{RHEUMATOID FACTOR REMISSION}

Rheumatoid arthritis (RA) is the most common inflammatory arthritis, affecting about $1 \%$ of the population. Left untreated, it can lead to irreversible joint deformities, disability, and increased mortality. Early identification and treatment of RA with disease-modifying antirheumatic drugs (DMARD) improve outcomes significantly ${ }^{1}$. Recently, new diagnostic criteria for RA [2010 American College of Rheumatology (ACR)/European League Against Rheumatism (EULAR) criteria] have been developed to identify patients earlier in the disease course ${ }^{2}$. The criteria include the presence and levels of anticitrullinated protein antibodies (ACPA) in addition to the previously used rheumatoid factor $(\mathrm{RF})^{2}$.

ACPA are as sensitive as RF for the diagnosis of RA; however, they are more specific. The most common clinically used ACPA, anticyclic citrullinated peptide-2 (anti-CCP2), has a specificity of $>95 \%$ in early RA compared to RF, with a specificity of $70 \%-80 \%{ }^{3}$. These

L. Barra, MD, Department of Medicine, Division of Rheumatology, St. Joseph's Health Care London, University of Western Ontario; V. Bykerk MD, Rebecca MacDonald Center for Arthritis and Autoimmune Disease, University of Toronto, Mount Sinai Hospital; Inflammatory Arthritis Center, Hospital for Special Surgery, Weill Cornell Medical School, Cornell University; J.E. Pope, MD, MPH, Department of Medicine, Division of Rheumatology, St. Joseph's Health Care London, University of Western Ontario; B.P. Haraoui, MD, Rheumatic Disease Unit, Institut de Rheumatologie; C.A. Hitchon, MD, MSc, Arthritis Center, University of Manitoba; J.C. Thorne, MD, Southlake Regional Health Centre; E.C. Keystone, MD, Rebecca MacDonald Center for Arthritis and Autoimmune Disease, University of Toronto, Mount Sinai Hospital; G. Boire, MD, MSc, Rheumatology Division, Université de Sherbrooke. Address correspondence to Dr. L. Barra, St. Joseph's Health Care, 268 Grosvenor Street, Room D2-160, London, Ontario N6A 4V2, Canada. E-mail: lbarra2@uwo.ca

Accepted for publication December 4, 2012.

Personal non-commercial use only. The Journal of Rheumatology Copyright (C) 2013. All rights reserved. 
antibodies are present in some individuals $>10$ years prior to disease onset, but appear to remain stable after RA diagnosis ${ }^{4,5,6}$. It is uncertain whether antibody levels fluctuate with treatment response or predict outcomes $7,8,9$, $10,11,12,13,14,15,16$. Therefore, the role of repeat antibody testing in the management of RA is unknown. A recent study has shown that changes in anti-CCP2 and RF status were not predictive of erosive disease ${ }^{16}$. That study identified another ACPA (anti-Sa) as a prognostic marker for erosions. However, there are few studies investigating the usefulness of ACPA and RF fluctuations in early inflammatory arthritis for predicting other disease outcomes, such as disease activity and physical function ${ }^{15}$.

Our objective was to determine whether ACPA or RF positivity change over time and whether these changes predict erosive disease and remission in a large prospective cohort of patients with early inflammatory arthritis (EIA), the Canadian Early Arthritis Cohort Study (CATCH). We also analyzed whether antibody levels at baseline predict disease outcomes.

\section{MATERIALS AND METHODS}

Patients. Data were collected on patients enrolled in the CATCH study, a multicenter observational prospective inception cohort of patients with EIA, from July 2007 to July 2011. Inclusion criteria for CATCH are age > 16 years, between 6 weeks and 12 months of persistent synovitis, and $\geq 2$ swollen joints or 1 swollen metacarpophalangeal or proximal interphalangeal joint with $\geq 1$ of the following: positive RF, positive ACPA, morning stiffness $>45 \mathrm{~min}$, response to nonsteroidal antiinflammatory drugs (NSAID), or painful metatarsophalangeal squeeze test. Patients were followed every 3 months using a standard protocol. Treatment with DMARD, NSAID, corticosteroids (oral, intramuscular, and/or intraarticular), and biologic agents was based on physician's discretion with the aim of obtaining zero swollen joints.

Our study was approved by the research ethics boards of all the centers involved and consent was obtained according to the Declaration of Helsinki.

$R F$ and ACPA. Patients were included if they had baseline and at least 12-month followup values for RF or ACPA. Data on antibodies were not available from 7 of 18 centers involved in CATCH. All other centers had baseline antibody values, but followup data were available in roughly $50 \%$ of enrolled patients. All RF assays measured IgM RF, but methods were not standardized across centers. Depending on the site, 2 different anti-CCP2 $\mathrm{IgG}$ kits were used (Euroimmune ${ }^{\mathrm{TM}}$ and Inova $^{\mathrm{TM}}$ ). Cutoff values for positivity used by the different assays were recorded in the database. For each individual patient, the same kit was always used for baseline and followup anti-CCP2 tests. There were no differences in study outcomes for the 2 different kits. For RF, moderate/high titers were arbitrarily set at $\geq 160$ units $/ \mathrm{ml}$. For ACPA, moderate/high titers were deemed to be $\geq 3$ times the upper limit of normal following the 2010 ACR/EULAR RA diagnostic criteria. The status of antibodies from inclusion to last available followup data was stratified into 4 categories: always negative, conversion (negative to positive), always positive, and reversion (positive to negative).

Disease variables and outcomes. Outcomes were assessed by a rheumatologist. Time of RA onset was defined as patient-reported commencement of symptoms that were persistent. The demographic information included age, sex, and smoking status (current smoker, ex-smoker, or never smoked). Clinical outcomes were regularly recorded at all centers every 3 months. Disease activity was determined using the Disease Activity Score-28 joint count (DAS28) and remission was defined as DAS28 $<2.6$.
Patient function was evaluated using the Health Assessment Questionnaire (HAQ). Swollen joint count (SJC) was a 28 -joint count. Presence or absence of erosions was determined using plain radiographs of the hands and feet performed at baseline and at 6 and every 12 months, as reported by the local radiologist and/or as reviewed by the treating rheumatologist. Radiographic data were available in roughly $90 \%$ of enrolled patients at baseline and $70 \%$ at followup. Presence or absence of erosions and new erosions was known but Sharp scores were not available. Followup antibody measurements were conducted at the same time as disease outcome measures.

Statistical analysis. Student $\mathrm{t}$ test or the Mann-Whitney $\mathrm{U}$ test was used to compare continuous variables; chi-square or Fisher's exact tests were used to compare categorical variables. ANOVA was used to determine risk of continuous outcomes for the different trajectories of antibodies. Multiple logistic regression was performed to evaluate whether antibody trajectory or level was an independent predictor of outcomes. Variables significantly associated with the outcomes of interest by univariate analyses were included in the logistic regression model if $\mathrm{p}<0.1$. The following variables were tested: age, sex, duration of disease, smoking history, baseline SJC, baseline HAQ score, presence of baseline erosions, baseline DAS28 score, and baseline treatment with antirheumatic agents. Bonferroni correction was performed for multiple comparisons. For analyses of the antibody trajectories, 6 comparisons were performed and significance was set at a $\mathrm{p}$ value of $0.05 / 6=0.0083$. For analyses of the antibody levels, 3 comparisons were performed and significance was set at a $\mathrm{p}$ value of $0.05 / 3=$ 0.017. Missing outcomes in followup data were not included in the analyses. Statistical analyses were performed using SAS software, version 9.3 (SAS Institute)

\section{RESULTS}

Patient characteristics. As of July 2012, 1431 patients were enrolled in $\mathrm{CATCH} ; 342$ had baseline and 12-month followup ACPA data available and 520 had RF data available. At 24 months, 277 and 376 patients had ACPA and RF data available, respectively. The baseline demographics, presence of erosions, DAS28, and HAQ score were not significantly different in the included versus excluded patients. Baseline characteristics are shown in Table 1. There were also no significant differences between patients with baseline and followup ACPA values and those with RF data available. Mean age was 52 years and disease duration at enrollment was 6.5 months. The population was $77.5 \%$ female. A history of smoking was reported in 58.8\%. The majority of patients met 1987 ACR RA criteria or 2010 ACR/EULAR criteria (67.2\% and $74.6 \%$, respectively).

ACPA-positive patients were younger, had longer disease duration, and were more likely to meet criteria for RA $(\mathrm{p}<0.0001)$ than ACPA-negative patients. Similarly, RF-positive patients had longer disease duration and were more likely to meet the RA criteria $(\mathrm{p}<0.05)$. There was no significant difference in smoking history between ACPA-positive and negative patients, but a higher proportion of RF-positive patients had a history of smoking compared to those who were RF-negative $(\mathrm{p}=0.0473)$. Most of the anti-CCP2-positive patients were also RF-positive $(78.1 \%)$, whereas $57.4 \%$ of ACPA-negative patients expressed RF $(\mathrm{p}<0.0001)$. RF-positive patients were also more likely to be ACPA-positive $(66.2 \%$ vs $36.1 \% ; \mathrm{p}<0.0001)$. 
Table 1. Patient characteristics at baseline.

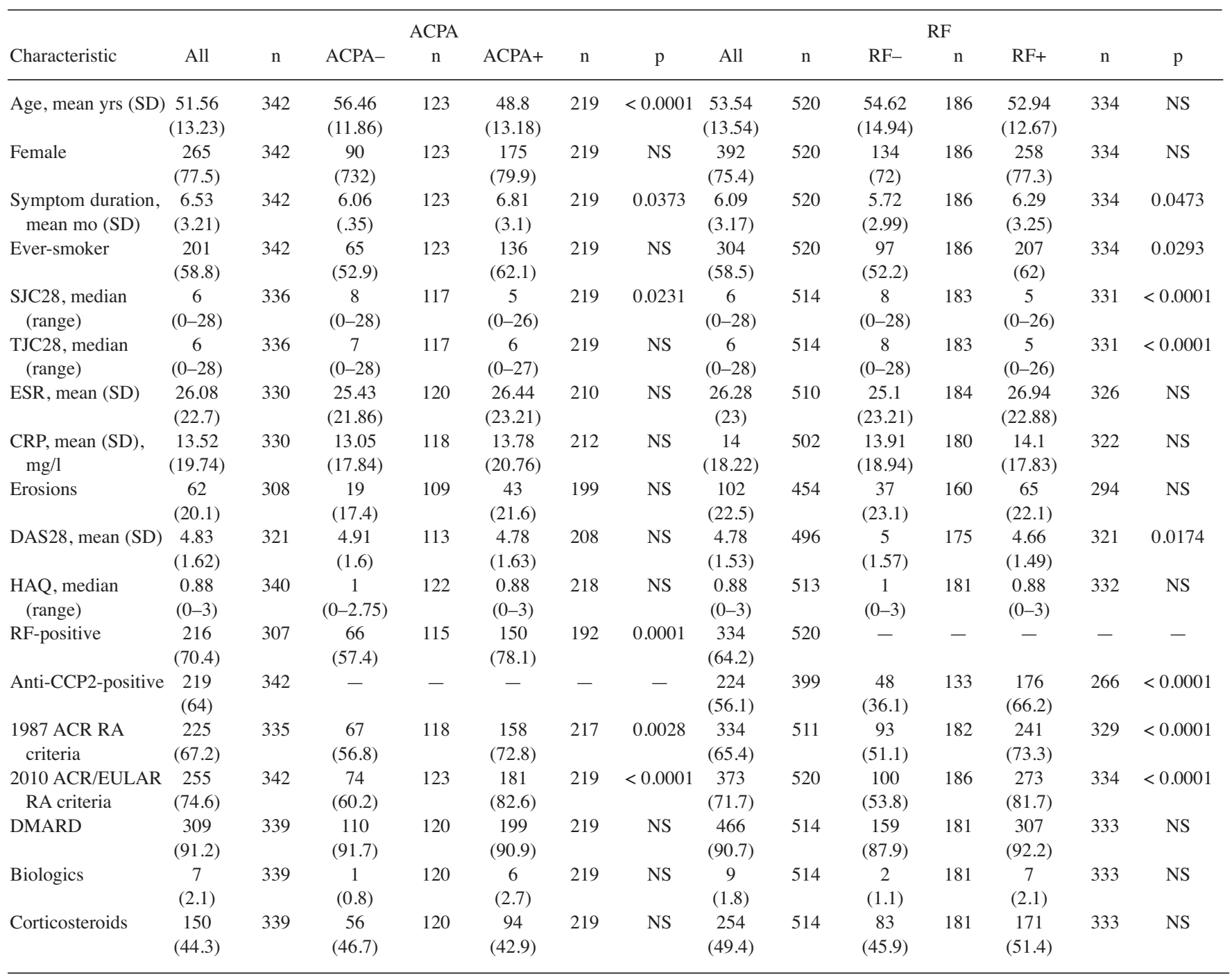

ACPA: anticitrullinated protein antibodies; RF: rheumatoid factor; SJC28: swollen joint count-28; TJC28: tender joint count-28; ESR: erythrocyte sedimentation rate; CRP: C-reactive protein; DAS28: Disease Activity Score-28; ACR: American College of Rheumatology; EULAR: European League Against Rheumatism; DMARD: disease-modifying antirheumatic drugs; NS: nonsignificant; HAQ: Health Assessment Questionnaire; RA: rheumatoid arthritis.

At inclusion, patients had moderate to severe disease, with median SJC of 6 (range 0-28)/28, TJC of 6 (range $0-28) / 28$, HAQ score $=0.88$ (range $0-3$ ), and mean DAS28 $=4.83($ SD 1.62). A large percentage (20.1\%) had erosive disease at baseline. More than $90 \%$ of patients were treated with a DMARD and $>40 \%$ were receiving corticosteroids (doses $<20 \mathrm{mg}$ daily). Treatment rates with antirheumatic drugs were not different in antibody-negative versus antibody-positive patients. SJC was significantly higher in ACPA-negative patients compared to ACPA-positive patients $(\mathrm{p}=0.0231)$, but other measures of disease activity were not different. RF-negative patients also had higher SJC $(\mathrm{p}<0.0001)$ and DAS28 score $(\mathrm{p}=0.0174)$ than RF-positive patients.

Tables 2 and 3 summarize clinical characteristics of patients at 12 and 24 months' followup. Clinical outcomes were significantly improved at 12 months' followup, with median SJC of 1 , median HAQ score $=0.25$, and mean DAS28 score $=2.84(\mathrm{p}<0.05)$. DAS remission was achieved in $52.6 \%$ of patients. These improvements continued at 24 months' followup. There was no significant change in the proportion of ACPA-positive and RF-positive patients at baseline and followup.

At 12 months' followup, a larger proportion of ACPA-positive patients had erosive disease compared to ACPA-negative patients $(33.1 \%$ vs $27.3 \%$, respectively; $\mathrm{p}=$ 0.0058). This difference was not seen at 24 months. At 24 months, ACPA-positive patients had a lower SJC than ACPA-negative patients $(\mathrm{p}=0.004)$. Other measures of disease activity at followup were not different between 
Table 2. Patient characteristics at followup by ACPA status.

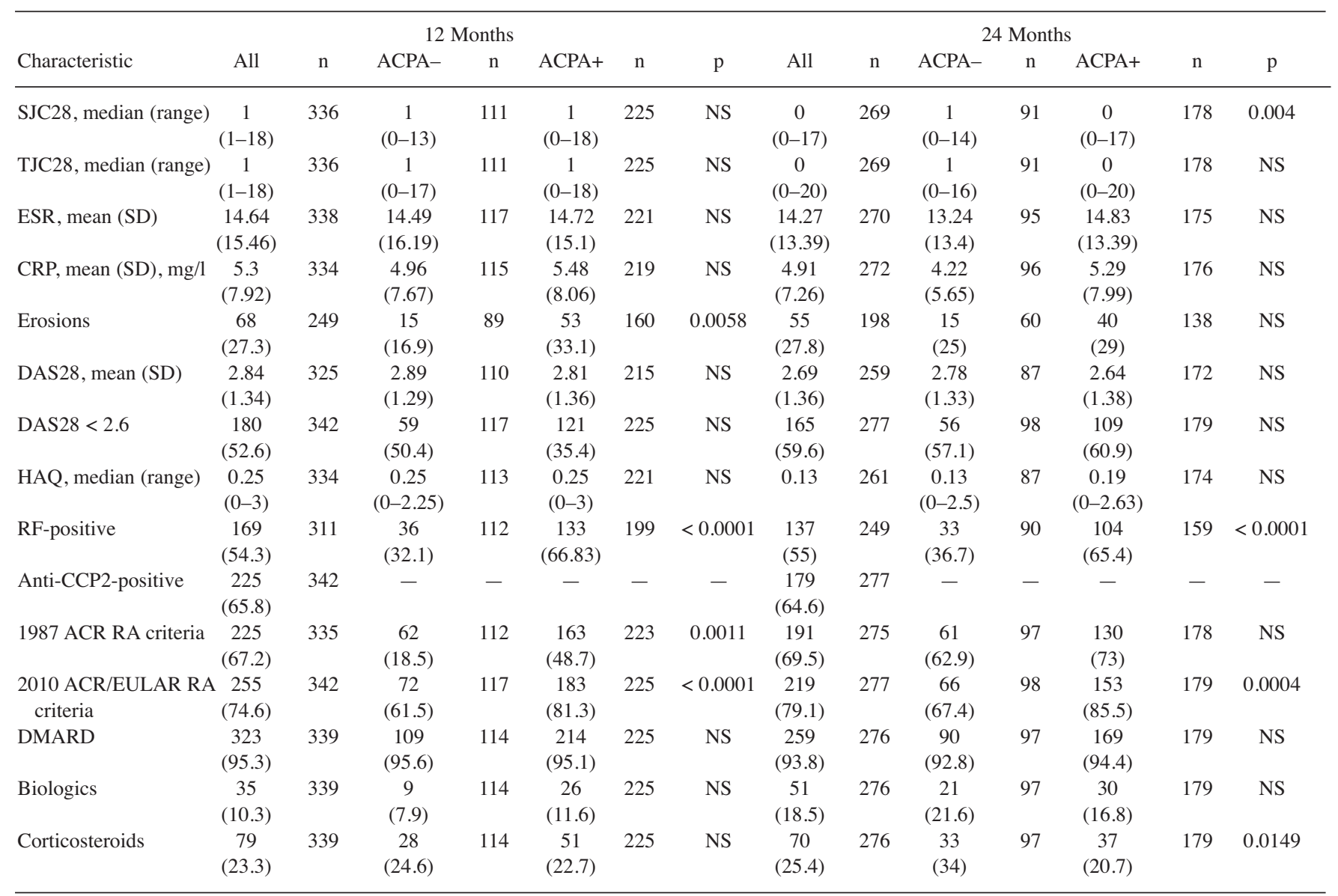

ACPA: anticitrullinated protein antibodies; RF: rheumatoid factor; SJC28: swollen joint count-28; TJC28: tender joint count-28; ESR: erythrocyte sedimentation rate; CRP: C-reactive protein; DAS28: Disease Activity Score-28; ACR: American College of Rheumatology; EULAR: European League Against Rheumatism; DMARD: disease-modifying antirheumatic drugs; NS: nonsignificant; HAQ: Health Assessment Questionnaire; RA: rheumatoid arthritis.

ACPA-positive and ACPA-negative patients and treatment with antirheumatic agents was similar. At 24 months ACPA-negative patients were more likely to be treated with corticosteroids (34\% vs $20.7 \%$; $\mathrm{p}=0.0149$ ). RF-positive patients appeared to have more severe disease at followup: they had higher DAS28 score, ESR, and CRP and were less likely to achieve remission $(\mathrm{p}<0.05)$. There was no difference in the rate of erosive disease in RF-positive versus RF-negative patients. RF-positive patients were less likely to be treated with a biologic agent at 24 months' followup (9.3\% vs $20.6 \%$; $\mathrm{p}=0.0022)$.

Trajectory of ACPA and RF over time. Fluctuations in both ACPA and RF antibody status occurred at the 12- and 24-month followup periods (Table 4). With ACPA, $10.6 \%$ of patients who were initially negative converted to positive at 12 months and $13.5 \%$ converted by 24 months. Similar findings were seen with RF ( $11.3 \%$ conversion at $12 \mathrm{mo}$ and $18.3 \%$ at $24 \mathrm{mo}$ ). Reversion was less frequent with ACPA (3.2\% positive at baseline and became negative at $12 \mathrm{mo}$ and $8.3 \%$ at $24 \mathrm{mo}$ ). RF frequently reverted over time:
$25.4 \%$ positive at baseline became negative at 12 months and $27.9 \%$ at 24 months' followup. Reversion was more common in patients with low RF levels: $52 / 85$ patients with low levels versus $33 / 85$ with high levels $(\mathrm{p}=0.0006)$ at 12 months; and 40/67 patients with low levels versus 27/67 with high levels $(\mathrm{p}<0.0001)$ at 24 months. ACPA levels were not significantly associated with the rate of reversion.

Effect of antibody trajectory on disease outcomes. Patients who were ACPA-positive at baseline and 12 months' followup were independently more likely to have erosive disease than patients who were always ACPA-negative (OR $3.86,95 \%$ CI 1.68, 8.92; Table 5). About RF, there was a lower likelihood of achieving remission (OR $0.59,95 \%$ CI $0.39,0.87)$ on univariate analysis; however, this association was not seen when multiple logistic regression was performed (Table 4). Also, we did not detect an association between ACPA or RF conversion and reversion and erosive disease or remission. With respect to SJC, HAQ, and DAS28 score, there were no statistically significant differences between the antibody trajectory groups at 12 or 24

Personal non-commercial use only. The Journal of Rheumatology Copyright (c) 2013. All rights reserved. 
Table 3. Patient characteristics at followup by RF status.

\begin{tabular}{|c|c|c|c|c|c|c|c|c|c|c|c|c|c|c|}
\hline Characteristic & All & $\mathrm{n}$ & RF- & $\mathrm{n}$ & $\mathrm{RF}+$ & $\mathrm{n}$ & $\mathrm{p}$ & All & $\mathrm{n}$ & $\mathrm{RF}-$ & $\mathrm{n}$ & $\mathrm{RF}+$ & $\mathrm{n}$ & $\mathrm{p}$ \\
\hline SJC28, median (range) & $\begin{array}{c}1 \\
(0-24)\end{array}$ & 514 & $\begin{array}{c}0 \\
(0-24)\end{array}$ & 244 & $\begin{array}{c}1 \\
(0-12)\end{array}$ & 270 & NS & $\begin{array}{c}0 \\
(0-17)\end{array}$ & 361 & $\begin{array}{c}0 \\
(0-17)\end{array}$ & 174 & $\begin{array}{c}0 \\
(0-16)\end{array}$ & 187 & NS \\
\hline TJC28, median (range) & $\begin{array}{c}1 \\
(0-25)\end{array}$ & 514 & $\begin{array}{c}1 \\
(0-25)\end{array}$ & 244 & $\begin{array}{c}1 \\
(0-19)\end{array}$ & 270 & NS & $\begin{array}{c}0 \\
(0-23)\end{array}$ & 361 & $\begin{array}{c}0 \\
(0-23)\end{array}$ & 174 & $\begin{array}{c}0 \\
(0-23)\end{array}$ & 187 & NS \\
\hline ESR, mean (SD) & $\begin{array}{c}14.49 \\
(14.88)\end{array}$ & 510 & $\begin{array}{l}11.72 \\
(11.35)\end{array}$ & 244 & $\begin{array}{c}17.03 \\
(17.14)\end{array}$ & 266 & $<0.0001$ & $\begin{array}{c}14.98 \\
(14)\end{array}$ & 367 & $\begin{array}{c}12.89 \\
(12.69)\end{array}$ & 178 & $\begin{array}{l}16.94 \\
(14.9)\end{array}$ & 189 & 0.0055 \\
\hline Erosions & $\begin{array}{c}87 \\
(27)\end{array}$ & 322 & $\begin{array}{c}39 \\
(25.7)\end{array}$ & 152 & $\begin{array}{c}48 \\
(28.2)\end{array}$ & 170 & NS & $\begin{array}{c}66 \\
(26.7)\end{array}$ & 247 & $\begin{array}{c}28 \\
(24.1)\end{array}$ & 116 & $\begin{array}{c}38 \\
(29)\end{array}$ & 131 & NS \\
\hline DAS28, mean (SD) & $\begin{array}{c}2.79 \\
(1.29)\end{array}$ & 493 & $\begin{array}{c}2.63 \\
(1.22)\end{array}$ & 230 & $\begin{array}{c}2.94 \\
(1.34)\end{array}$ & 263 & 0.0093 & $\begin{array}{c}2.71 \\
(1.35)\end{array}$ & 347 & $\begin{array}{c}2.58 \\
(1.31)\end{array}$ & 166 & $\begin{array}{c}2.82 \\
(1.38)\end{array}$ & 181 & NS \\
\hline DAS28 $<2.6$ & $\begin{array}{c}272 \\
(52.3)\end{array}$ & 520 & $\begin{array}{l}145 \\
(58)\end{array}$ & 250 & $\begin{array}{l}127 \\
(47)\end{array}$ & 270 & 0.0124 & $\begin{array}{c}221 \\
(58.8)\end{array}$ & 376 & $\begin{array}{c}113 \\
(62.1)\end{array}$ & 182 & $\begin{array}{c}108 \\
(55.7)\end{array}$ & 194 & NS \\
\hline Anti-CCP2-positive & $\begin{array}{c}203 \\
(62.3)\end{array}$ & 326 & $\begin{array}{c}69 \\
(45.4)\end{array}$ & 152 & $\begin{array}{l}134 \\
(77)\end{array}$ & 174 & $<0.0001$ & $\begin{array}{c}150 \\
(60.5)\end{array}$ & 248 & $\begin{array}{c}59 \\
(47.6)\end{array}$ & 124 & $\begin{array}{c}91 \\
(73.7)\end{array}$ & 124 & $<0.0001$ \\
\hline 1987 ACR RA criteria & $\begin{array}{c}334 \\
(65.4)\end{array}$ & 511 & $\begin{array}{c}142 \\
(58.4)\end{array}$ & 243 & $\begin{array}{c}192 \\
(71.6)\end{array}$ & 268 & 0.0017 & $\begin{array}{c}242 \\
(64.9)\end{array}$ & 373 & $\begin{array}{c}111 \\
(61.3)\end{array}$ & 181 & $\begin{array}{c}131 \\
(68.2)\end{array}$ & 192 & NS \\
\hline $\begin{array}{l}2010 \text { ACR/EULAR RA } \\
\text { criteria }\end{array}$ & $\begin{array}{c}373 \\
(71.7)\end{array}$ & 520 & $\begin{array}{l}160 \\
(64)\end{array}$ & 250 & $\begin{array}{c}213 \\
(78.9)\end{array}$ & 270 & 0.0002 & $\begin{array}{c}278 \\
(73.9)\end{array}$ & 376 & $\begin{array}{c}123 \\
(67.6)\end{array}$ & 182 & $\begin{array}{c}155 \\
(79.9)\end{array}$ & 194 & 0.0066 \\
\hline DMARD & $\begin{array}{c}481 \\
(93.6)\end{array}$ & 514 & $\begin{array}{c}231 \\
(94.7)\end{array}$ & 244 & $\begin{array}{c}250 \\
(92.6)\end{array}$ & 270 & NS & $\begin{array}{l}347 \\
(93)\end{array}$ & 373 & $\begin{array}{l}171 \\
(95)\end{array}$ & 180 & $\begin{array}{c}176 \\
(91.2)\end{array}$ & 193 & NS \\
\hline Biologics & $\begin{array}{c}50 \\
(9.7)\end{array}$ & 514 & $\begin{array}{c}29 \\
(11.9)\end{array}$ & 244 & $\begin{array}{c}21 \\
(7.8)\end{array}$ & 270 & NS & $\begin{array}{c}55 \\
(14.8)\end{array}$ & 373 & $\begin{array}{c}37 \\
(20.6)\end{array}$ & 180 & $\begin{array}{c}18 \\
(9.3)\end{array}$ & 193 & 0.0022 \\
\hline Corticosteroids & $\begin{array}{c}122 \\
(23.7)\end{array}$ & 514 & $\begin{array}{c}56 \\
(23)\end{array}$ & 244 & $\begin{array}{c}66 \\
(24.4)\end{array}$ & 270 & NS & $\begin{array}{c}94 \\
(25.2)\end{array}$ & 373 & $\begin{array}{c}38 \\
(21.1)\end{array}$ & 180 & $\begin{array}{c}56 \\
(29)\end{array}$ & 193 & NS \\
\hline
\end{tabular}

Anti-CCP: anticyclic citrullinated peptide; RF: rheumatoid factor; SJC28: swollen joint count-28; TJC28: tender joint count-28; ESR: erythrocyte sedimentation rate; CRP: C-reactive protein; DAS28: Disease Activity Score-28; ACR: American College of Rheumatology; EULAR: European League Against Rheumatism; DMARD: disease-modifying antirheumatic drugs; NS: nonsignificant; HAQ: Health Assessment Questionnaire; RA: rheumatoid arthritis.

Table 4. ACPA and RF trajectory over followup period.

\begin{tabular}{lcccc}
\hline & \multicolumn{2}{c}{12 Months Followup } & \multicolumn{2}{c}{ 24 Months Followup } \\
Status & $\begin{array}{c}\text { ACPA, } \\
\mathrm{n}(\%)\end{array}$ & $\mathrm{n}(\%)$ & $\begin{array}{c}\text { ACPA, } \\
\mathrm{n}(\%)\end{array}$ & $\begin{array}{c}\text { RF, } \\
\mathrm{n}(\%)\end{array}$ \\
\hline Negative at baseline & 123 & 186 & 96 & 136 \\
Negative at followup & $110(89.4)$ & $165(88.7)$ & $83(86.4)$ & $115(84.6)$ \\
Conversion at followup & $13(10.6)$ & $21(11.3)$ & $13(13.5)$ & $21(18.3)$ \\
Positive at baseline & 219 & 334 & 181 & 240 \\
Positive at followup & $212(96.8)$ & $249(74.6)$ & $166(91.7)$ & $173(72.1)$ \\
Reversion at followup & $7(3.2)$ & $85(25.4)$ & $15(8.3)$ & $67(27.9)$ \\
\hline
\end{tabular}

ACPA: anticitrullinated protein antibodies; RF: rheumatoid factor.

months' followup (data not shown). Baseline antibody status or trajectory over time was not significantly associated with treatment with antirheumatic drugs at baseline or followup in multivariable analysis (data not shown).

Effect of ACPA and RF levels on clinical outcomes. Forty percent of patients had moderate or high levels of RF and $56 \%$ had moderate or high levels of ACPA. SJC, HAQ score, and DAS28 score at followup was not significantly different based on antibody level at baseline (data not shown). There was also no significant association between baseline levels of RF and erosions or DAS remission (Table 5). The ACPA moderate/high-positive group had an independent and statistically significant higher risk of erosive disease at 12-month followup (OR 3.4, 95\% CI 1.61, 
Table 5. Effect of antibody trajectory and level on erosions and DAS remission.

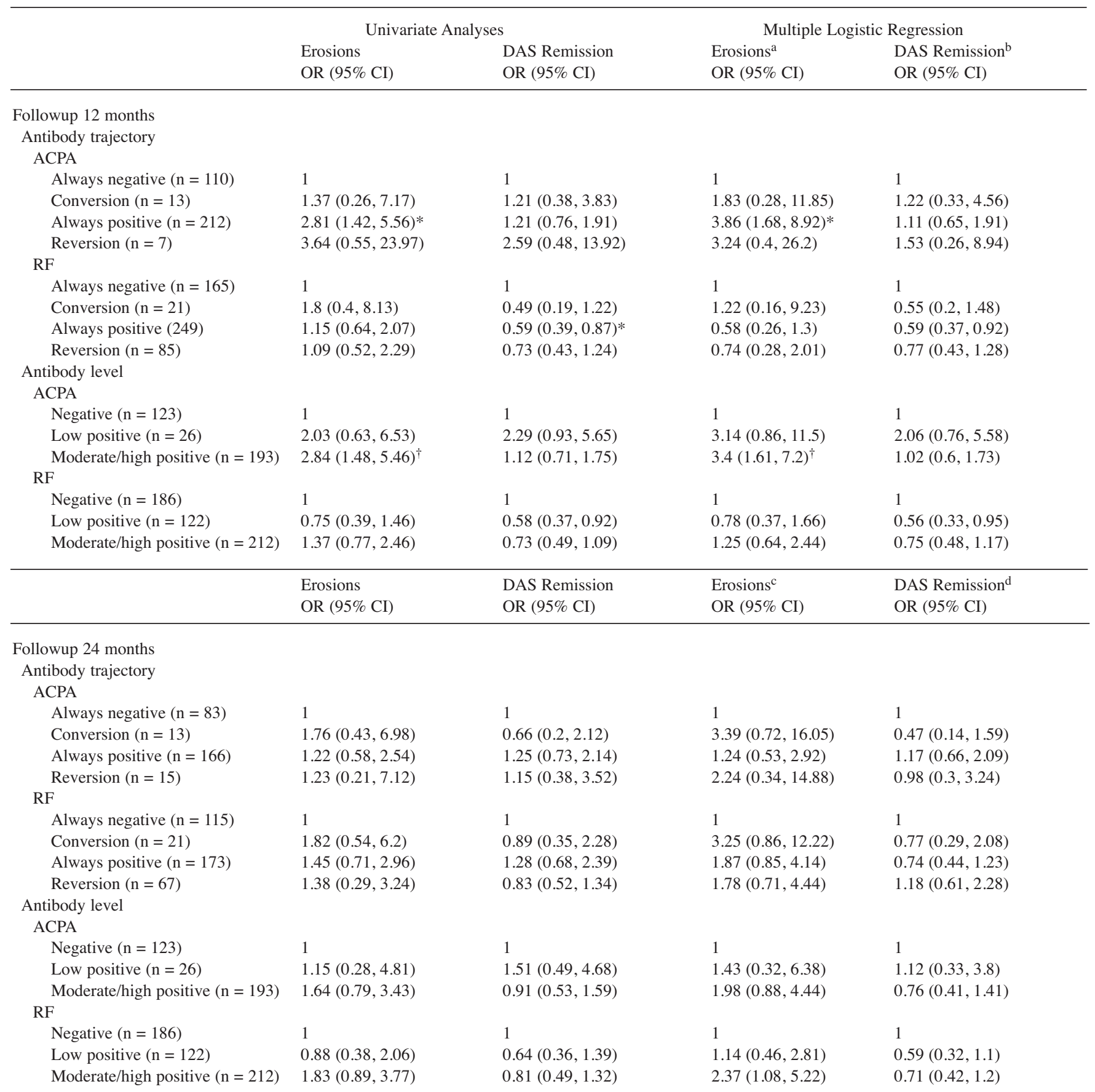

Multiple logistic regression model included the following variables associated with the outcome in univariate analyses with $\mathrm{p}<0.1$ : ${ }^{\mathrm{a}}$ baseline erosions, CRP (baseline ACPA positivity for analyses of RF trajectory and levels); ${ }^{b}$ age, sex, smoking, baseline DAS28, HAQ, SJC; ${ }^{\mathrm{c}}$ baseline erosions, DAS28; ${ }^{\mathrm{d}}$ age, baseline DAS28, HAQ. ACPA: anticitrullinated protein antibodies; RF: rheumatoid factor; CRP: C-reactive protein; DAS28: Disease Activity Score-28; HAQ: Health Assessment Questionnaire 28 score; SJC: swollen joint count. Bonferroni correction for multiple comparisons was formed. $* \mathrm{p}<0.0083 ;{ }^{\dagger} \mathrm{p}<0.017$.

7.2). This increased risk was not detected at 24 months. ACPA levels at baseline did not appear to predict DAS remission (Table 5).

\section{DISCUSSION}

RF and ACPA are the most common clinically used RA-associated antibodies. It is unclear whether repeated 
measurements of these antibodies throughout the course of disease are useful in the management of patients with early inflammatory arthritis. Therefore, we investigated fluctuations of RF and ACPA in a prospective inception cohort of EIA and determined whether changes in antibody status predicted disease outcomes.

Our data revealed significant fluctuations in antibody status over a median followup period of 21 months: 13.5\% of patients who were initially ACPA-negative became positive by 24 months' followup. Conversion to positive status occurred despite significant improvements in disease activity and function. Reversion rate was lower at $8.3 \%$. The rate of RF fluctuations was very high ( $18 \%$ conversion and $28 \%$ reversion at $24 \mathrm{mo}$ ). Other studies of EIA or early RA have shown lower rates of ACPA conversion of $2 \%$ to $6 \% 16,17,18,19,20$. ACPA and RF status in established RA have also been reported to be stable ${ }^{6}$. However, with respect to $\mathrm{RF}$, our findings are consistent with recent studies that also show high rates of fluctuations for RF $(13 \%-35 \%)^{18,19,20}$. We found that reversion to negative antibody status appeared to occur more frequently with low RF levels, but not ACPA. Also, half of the ACPA and RF converters had moderate to high levels. Since ACPA has a very high specificity for RA diagnosis, the significant conversion rate in our study suggests a potential diagnostic role for repeating antibody testing in patients with undifferentiated arthritis.

Many studies have investigated RF and ACPA as predictors of disease severity in RA. The majority of studies have shown that baseline ACPA is an independent predictor of erosive disease in both early and established RA at 1 to 10 years' followup $15,17,21,22,23,24$. These support our finding that persistent ACPA positivity is independently associated with erosive disease. RF has also been shown to predict erosions ${ }^{25,26}$, but this may not be an independent effect $^{21,22,23}$ except in patients with high RF titer ${ }^{27}$. We did not find that RF positivity even at higher levels was independently associated with erosive disease.

Studies investigating the prognostic utility of RF and ACPA for other disease outcomes have yielded conflicting results. Van der Linden, et al found that RF and ACPA-positive patients were less likely to achieve remission at 7 years' followup ${ }^{25}$. Farragher, et al found that the presence of ACPA, but not RF, was associated with higher SJC, DAS score, and HAQ score ${ }^{22}$. However, other studies found that the association was only with high-titer ACPA, was lost at longer followup times, or was present only in RF-negative patients ${ }^{17,24,28}$. Wagner, et al showed that ACPA did not predict unfavorable outcomes, but that RF $\operatorname{did}^{29}$. Ursum, et al and van den Broek, et al found similar DAS28 scores, rates of DAS remission, and physical function in ACPA-positive versus ACPA-negative patients ${ }^{19,30}$.

We also showed that RF and ACPA positivity or conversion from negative to positive did not predict worse
DAS28 and HAQ scores or remission rates. Our results are consistent with the findings from the Norfolk Arthritis Register ${ }^{18}$. In another Canadian study, Guzian, et al also found that fluctuations in ACPA and RF were not predictive of erosive disease ${ }^{16}$. However, another anti-citrullinated peptide antibody (anti-Sa) was associated with higher rates of erosive disease. Other studies have also suggested that anti-modified citrullinated vimentin (anti-MCV) is better than ACPA at prognostication in $\mathrm{RA}^{23}$. Unfortunately, anti-Sa and anti-MCV were not measured in the CATCH cohort. Although the study by Guzian, et al investigated a Canadian early arthritis cohort, none of the patients included in that study were enrolled in $\mathrm{CATCH}$.

The lack of association between RF positivity and worse disease outcomes may be partly explained by the higher DAS scores of RF-negative patients at baseline. These patients were more likely to be treated with biologic agents at followup, but outcomes in RF-positive and RF-negative patients remained similar after accounting for this difference. Conversely, ACPA patients did not have worse disease activity at baseline. In addition, ACPA-positive patients were not treated more aggressively with disease-modifying agents even though physicians in this study were not blinded to antibody status. ACPA-negative patients were more likely to require corticosteroids at followup compared to ACPA-positive patients. It is possible that antibody-negative patients are less responsive to methotrexate and biologic therapies ${ }^{31,32,33}$, which may contribute to our findings.

The disparate findings from our study compared to other studies of early inflammatory arthritis may be secondary to differences in population and study design. For example, the followup time in our study was shorter than others and RA-associated antibodies may be predictive of worse outcomes only later in the disease course ${ }^{28}$. Other baseline features, such as disease duration at inclusion, sex, smoking status, and disease activity, were similar across all studies $16,18,23$. However, different proportions of patients with undifferentiated arthritis and slight differences in treatment strategies in these studies may also account for differing results. The strengths of our study include the use of a large, prospective cohort of patients with EIA, including those with undifferentiated arthritis. This study used a "real-world" cohort reflecting actual practice, in which patients with inflammatory arthritis were investigated and treated based on physician preferences from both tertiary care and community settings. It is the first North American multicenter study determining whether fluctuations in RA and ACPA predict various disease outcomes. Our study has several limitations: ACPA testing is not uniformly covered by the public healthcare system in Canada; therefore, it was not regularly tested in all centers. However, there were no significant differences in baseline demographics and disease activity between the included and excluded populations

Personal non-commercial use only. The Journal of Rheumatology Copyright @ 2013. All rights reserved. 
(data not shown). The sample size in some of the trajectory groups was relatively small. Radiographs were read locally and data on modified Sharp scores were not collected. Although the laboratory tests were not standardized centrally, the same tests were used to measure baseline and followup RF and ACPA in each patient. Also, there was no difference in results between the 2 anti-CCP2 kits used (data not shown). Nonetheless these findings need to be corroborated in other cohort studies.

We found that fluctuations in RF and ACPA up to 24 months' followup are common. Since ACPA is highly specific for RA, repeat testing at followup in patients with undifferentiated arthritis may be beneficial. Patients who remained positive for ACPA at 12 months' followup were more likely to have erosive disease. However, there is no consensus on the prognostic utility of ACPA and RF in early RA for other outcome measures. In our study, these antibodies did not predict DAS28 scores, HAQ scores, or DAS remission. Further studies are needed to identify other prognostic markers in EIA.

\section{ACKNOWLEDGMENT}

The authors thank all patients involved in the study. Our thanks to McDougall Associates and Mount Sinai Hospital, University of Toronto, for database management; and Dr. Ye Sun and Larry Stitt, The University of Western Ontario, for statistical support.

\section{REFERENCES}

1. Lard LR, Visser H, Speyer I, vander Horst-Bruinsma IE, Zwinderman AH, Breedveld FC, et al. Early versus delayed treatment in patients with recent-onset rheumatoid arthritis: comparison of two cohorts who received different treatment strategies. Am J Med 2001;111:446-51.

2. van der Linden MP, Knevel R, Huizinga TW, van der Helm-van Mil AH. Classification of rheumatoid arthritis: comparison of the 1987 American College of Rheumatology criteria and the 2010 American College of Rheumatology/European League Against Rheumatism criteria. Arthritis Rheum 2011;63:37-42.

3. Whiting PF, Smidt N, Sterne JA, Harbord R, Burton A, Burke M, et al. Systematic review: accuracy of anti-citrullinated peptide antibodies for diagnosing rheumatoid arthritis. Ann Intern Med 2010;152:456-64.

4. Rantapää-Dahlqvist S, de Jong BA, Berglin E, Hallmans G, Wadell $\mathrm{G}$, Stenlund $\mathrm{H}$, et al. Antibodies against cyclic citrullinated peptide and $\operatorname{Ig} \mathrm{A}$ rheumatoid factor predict the development of rheumatoid arthritis. Arthritis Rheum 2003;48:2741-9.

5. Nielen MM, van Schaardenburg D, Reesink HW, van de Stadt RJ, van der Horst-Bruinsma IE, de Koning MH, et al. Specific autoantibodies precede the symptoms of rheumatoid arthritis: a study of serial measurements in blood donors. Arthritis Rheum 2004:50:380-6

6. Barra L, Pope J, Bessette L, Haraoui B, Bykerk V. Lack of seroconversion of rheumatoid factor and anti-cyclic citrullinated peptide in patients with early inflammatory arthritis: a systematic literature review. Rheumatology 2011;50:311-6.

7. Mikuls TR, O'Dell JR, Stoner JA, Parrish LA, Arend WP, Norris $\mathrm{JM}$, et al. Association of rheumatoid arthritis treatment response and disease duration with declines in serum levels of IgM rheumatoid factor and anti-cyclic citrullinated peptide antibody. Arthritis Rheum 2004;50:3776-82.
8. Yazdani-Biuki B, Stadlmaier E, Mulabecirovic A, Brezinschek R, Tilz G, Demel U, et al. Blockade of tumour necrosis factor \{alpha\} significantly alters the serum level of IgG- and IgA-rheumatoid factor in patients with rheumatoid arthritis. Ann Rheum Dis 2005;64:1224-6.

9. Alessandri C, Bombardieri M, Papa N, Cinquini M, Magrini L, Tincani A, et al. Decrease of anti-cyclic citrullinated peptide antibodies and rheumatoid factor following anti-TNFalpha therapy (infliximab) in rheumatoid arthritis is associated with clinical improvement. Ann Rheum Dis 2004;63:1218-21.

10. De Rycke L, Verhelst X, Kruithof E, Van den Bosch F, Hoffman IE, Veys EM, et al. Rheumatoid factor, but not anti-cyclic citrullinated peptide antibodies, is modulated by infliximab treatment in rheumatoid arthritis. Ann Rheum Dis 2005;64:299-302.

11. Atzeni F, Sarzi-Puttini P, Dell'Acqua D, de Portu S, Cecchini G, Cruini CD, et al. Adalimumab clinical efficacy is associated with rheumatoid factor and anti-cyclic citrullinated peptide antibody titer reduction: a one-year prospective study. Arthritis Res Ther 2006;8:R3

12. Vis M, Bos WH, Wolbink G, Voskuyl AE, Twisk JW, Van de Stadt $\mathrm{R}$, et al. IgM-rheumatoid factor, anti-cyclic citrullinated peptide, and anti-citrullinated human fibrinogen antibodies decrease during treatment with the tumor necrosis factor blocker infliximab in patients with rheumatoid arthritis. J Rheumatol 2008;35:425-8.

13. Cambridge G, Leandro MJ, Edwards JC, Ehrenstein MR, Salden M, Bodman-Smith M, et al. Serologic changes following B lymphocyte depletion therapy for rheumatoid arthritis. Arthritis Rheum 2003;48:2146-54

14. Pope RM, Lessard J, Nunnery E. Differential effects of therapeutic regimens on specific classes of rheumatoid factor. Ann Rheum Dis 1986;45:183-9.

15. Taylor P, Gartemann J, Hsieh J, Creeden J. A systematic review of serum biomarkers anti-cyclic citrullinated peptide and rheumatoid factor as tests for rheumatoid arthritis. Autoimmune Dis 2011;2011:815038.

16. Guzian MC, Carrier N, Cossette P, de Brum-Fernandes AJ, Liang P, Ménard HA, et al. Outcomes in recent-onset inflammatory polyarthritis differ according to initial titers, persistence over time, and specificity of the autoantibodies. Arthritis Care Res 2010;62:1624-32.

17. Kastbom A, Strandberg G, Lindroos A, Skogh T. Anti-CCP antibody test predicts the disease course during 3 years in early rheumatoid arthritis (the Swedish TIRA project). Ann Rheum Dis 2004;63:1085-9.

18. Burr ML, Viatte S, Bukhari M, Plant D, Symmons DP, Thomson W, et al. Long-term stability of anti-cyclic citrullinated peptide antibody status in patients with early inflammatory polyarthritis. Arthritis Res Ther 2012;14:R109.

19. Ursum J, Bos WH, van Dillen N, Dijkmans BA, van Schaardenburg D. Levels of anti-citrullinated protein antibodies and IgM rheumatoid factor are not associated with outcome in early arthritis patients: a cohort study. Arthritis Res Ther 2010;12:R8.

20. Ursum J, Bos WH, van de Stadt RJ, Dijkmans BA, van Schaardenburg D. Different properties of ACPA and IgM-RF derived from a large dataset: further evidence of two distinct autoantibody systems. Arthritis Res Ther 2009;11:R75.

21. Forslind K, Ahlmén M, Eberhardt K, Hafström I, Svensson B; BARFOT Study Group. Prediction of radiological outcome in early rheumatoid arthritis in clinical practice: role of antibodies to citrullinated peptides (anti-CCP). Ann Rheum Dis 2004;63:1090-5.

22. Farragher TM, Lunt M, Plant D, Bunn DK, Barton A, Symmons DP. Benefit of early treatment in inflammatory polyarthritis patients with anti-cyclic citrullinated peptide antibodies versus those without antibodies. Arthritis Care Res 2010;62:664-75.

23. Syversen SW, Goll GL, van der Heijde D, Landewé R, Lie BA, 
Odegård SD, et al. Prediction of radiographic progression in rheumatoid arthritis and the role of antibodies against mutated citrullinated vimentin: results from a 10-year prospective study. Ann Rheum Dis 2010;69:345-51.

24. Nell VP, Machold KP, Stamm TA, Eberl G, Heinzl H, Uffmann M, et al. Autoantibody profiling as early diagnostic and prognostic tool for rheumatoid arthritis. Ann Rheum Dis 2005;64:1731-6.

25. van der Linden MP, van der Woude D, Ioan-Facsinay A, Levarht EW, Stoeken-Rijsbergen G, Huizinga TW, et al. Value of anti-modified citrullinated vimentin and third-generation anti-cyclic citrullinated peptide compared with second-generation anti-cyclic citrullinated peptide and rheumatoid factor in predicting disease outcome in undifferentiated arthritis and rheumatoid arthritis. Arthritis Rheum 2009;60:2232-41.

26. Mewar D, Coote A, Moore DJ, Marinou I, Keyworth J, Dickson $\mathrm{MC}$, et al. Independent associations of anti-cyclic citrullinated peptide antibodies and rheumatoid factor with radiographic severity of rheumatoid arthritis. Arthritis Res Ther 2006;8:R128.

27. Kroot EJ, de Jong BA, van Leeuwen MA, Swinkels H, van den Hoogen FH, van't Hof M, et al. The prognostic value of anti-cyclic citrullinated peptide antibody in patients with recent-onset rheumatoid arthritis. Arthritis Rheum 2000;43:1831-5.

28. Quinn MA, Gough AK, Green MJ, Devlin J, Hensor EM, Greenstein A, et al. Anti-CCP antibodies measured at disease onset help identify seronegative rheumatoid arthritis and predict radiological and functional outcome. Rheumatology 2006; 45:478-80
29. Wagner E, Ammer K, Kolarz G, Krajnc I, Palkonyai E, Scherak O, et al. Predicting factors for severity of rheumatoid arthritis: a prospective multicenter cohort study of 172 patients over 3 years Rheumatol Int 2007;27:1041-8.

30. van den Broek M, Dirven L, Klarenbeek NB, Molenaar TH, Han $\mathrm{KH}$, Kerstens PJ, et al. The association of treatment response and joint damage with ACPA-status in recent-onset RA: A subanalysis of the 8-year follow-up of the BeSt study. Ann Rheum Dis 2012;71:245-8.

31. Cuchacovich M, Catalan D, Wainstein E, Gatica H, Soto L, Aravena $\mathrm{O}$, et al. Basal anti-cyclic citrullinated peptide (anti-CCP) antibody levels and a decrease in anti-CCP titres are associated with clinical response to adalimumab in rheumatoid arthritis. Clin Exp Rheumatol 2008;26:1067-73.

32. Lal P, Su Z, Holweg CT, Silverman GJ, Schwartzman S, Kelman A, et al. Inflammation and autoantibody markers identify rheumatoid arthritis patients with enhanced clinical benefit following rituximab treatment. Arthritis Rheum 2011;63:3681-91.

33. van Dongen H, van Aken J, Lard LR, Visser K, Ronday HK, Hulsmans HM, et al. Efficacy of methotrexate treatment in patients with probable rheumatoid arthritis: a double-blind, randomized, placebo-controlled trial. Arthritis Rheum 2007;56:1424-32. 